\title{
Some Points in the Anatomy of the Leaf of Welwitschia mirabilis.
}

BY

\section{H. TAKEDA.}

With Plate XXIX and five Figures in the Text.

SINCE the publication of Hooker's elaborate monograph (8), internal $S$ features of this singular plant have already been investigated by various botanists, such as de Bary (4), Bertrand (1), Strasburger (17, 18), and Bower $(2,3)$. Quite recently Miss Sykes (now Mrs. Thoday) has made contributions to our previous knowledge in two papers $(19,20)$, in which she refers to the publications of the previous workers. It seems to me, however, that there are still some interesting anatomical features left undescribed, and also certain points requiring a thorough examination.

The material of the adult leaf used for my study was dried. It was boiled in water for a short time and then soaked in spirit, and it shows the structure wonderfully well preserved. The whole leaf is $60 \mathrm{~cm}$. in length and deeply cut into strips about $2 \mathrm{~cm}$. in breadth. These strips are inserted on a stem $10 \mathrm{~cm}$. in height, $17 \mathrm{~cm}$. in the longer diameter, with muchbranched roots. The cotyledon and young leaf of seedlings which were raised by Mr. Hales of Chelsea Physic Garden were also examined for comparison. One of the seedlings was about three weeks old and bore two cotyledons nearly $3 \mathrm{~cm}$. in length, and $5 \frac{1}{2} \mathrm{~mm}$. in breadth. In this stage the leaves had not yet developed, but showed themselves as small projections at the apex of the hypocotyl between the connate bases of the cotyledons. The other seedling was about seven months old, and had developed young leaves about $6 \mathrm{~cm}$. long.

Sections were cut by hand or microtome in three directions: transverse, horizontal (parallel to the surface of the leaf), and longitudinal (radial to the vascular bundle). Certain elements of tissue were macerated out by means of Schultze's macerating fluid. Various kinds of reagents and simple as well as combination stains were used. Some sections were mounted for permanent preparations in Canada balsam, or in glycerinejelly either coloured or uncoloured.

The Nervation. The nervation of the leaf is a simple sort of 'nervatio [Annals of Botany, Vol. XXVII. No. CVI. April, 1913. 
Goniopteridis', which becomes more or less irregular owing to the aberrant path of the lateral transverse branches or veins, as already described by de Bary (4, p. 303) and Sykes (19, p. I8I). One point to note here is that the short branch given off from the transverse branches is always directed towards the apex, and never towards the base of the leaf!

The cotyledon is elliptical-oblanceolate and connate at the base, and shows a similar kind of nervation in a looser and more or less irregular manner. Two bundles enter each cotyledon, and traverse the latter straight up to the apex, taking a parallel course. At the very base of the cotyledon, which is connate and forms a very short tube, each of these two bundles gives off a lateral bundle ; this again divides, a little further up, into two. Thus there are six main bundles present in the cotyledon: two central, two lateral, and two marginal ones. The 'marginal' bundles are much weaker than the rest and die away about midway of the whole length of the cotyledon, while the 'lateral' bundles also do not really reach the apex. The veins are much more irregular and more oblique than in the adult leaf. These veins anastomose or end blindly, just as in the foliage leaf (Pl. XXIX, Fig. I).

The nervation with three pairs of bundles derived from the double leaf-trace seems to me to be the phylogenetically primary one, and this design is also found in the young leaf.

It has been stated both by Bower (2, p. 19) and by Hill and de Fraine $\left(7\right.$, p. $\left.3^{2} 3\right)$ that four bundles enter the cotyledon. They seem to have not noticed the real base of the cotyledon and taken the connate portion of the cotyledon for a structure belonging to the hypocotyl.

The nervation of the young leaf of my material shows a very interesting feature. In the portion about $3 \mathrm{~cm}$. in distance from the apex the nervation is practically the same as in the cotyledon, i. e. it shows six main bundles and very oblique veins (cf. Fig. I). However, a difference is to be noticed, inasmuch as the 'marginal' and 'lateral' bundles do not directly fuse with the 'central' ones, but are only connected, transversely, by the veins. ${ }^{1}$ Further downwards there are to be seen new bundles of different lengths running parallel to the long axis of the leaf. These lie between the three pairs of bundles above noted, as already described by Bower $(3, \mathrm{p} .586)$. Thus a direct connexion between the central pair of bundles and the 'lateral' + ' marginal' ones on either side, as a result of branching, such as we see in the case of the cotyledon, does not exist. This is brought about by the new bundles of secondary origin. The central pair of bundles, therefore, only form the direct continuation of the hypocotyledonary bundles; all the others are connected together by the plexus of vascular bundles in the 'crown', which are differentiated later (cf. 3 , p. $5^{8} 5$ et seq.).

1 For the section of this stage cf. Bower (3), Pl. XXXII, Fig. 7. My 'marginal' and 'lateral' bundles correspond to his 'secondary vascular bundles'. 
The constant addition of new bundles at the base of the adult leaf is the peculiarity of Welwitschia, which is not known anywhere else. The phylogenetically primary design of the nervation is somewhat blurred in the young leaf, and is completely obliterated in the adult leaf, but it is well retained in the cotyledon.

The Epidermis. The epidermal cell is practically prismatic, with a thin inner wall and very much thickened outer wall (Figs. 3, 6). The cell-lumen is very much narrowed towards the outer side of the cell, owing to the enormous thickening of the lateral walls. Two layers can be distinguished in the outer wall : a cuticularized layer and a non-cutinized layer. The cuticularized layer contains a considerable amount of minute crystals and granules of calcium oxalate. The non-cutinized layer chiefly consists of cellulose and does not react to phloroglucin. The middle lamella of the partition-wall between two epidermal cells is very conspicuous. The cuticle is not very thick and measures about $2.5 \mu$ in the thickest part, and is far thinner on the guard cell.

The description and figure of the epidermis given by Sykes $(19, \mathrm{p} .180)$ differ surprisingly from my own. One of the most striking things is that the outermost layer, which should be nothing else but cuticle, is said to come down at the corner of the cells through the middle (cuticularized) layer and touches the cellulose wall. This should be the middle lamella of the partition-wall between two contiguous epidermal cells. It might appear as if it were a projection of the cuticle, but it is not a continuation of the latter at all. I was also at a loss to understand the misty covering of the epidermal cells delineated in her Fig. 3. It seems to me that it may represent a portion of the outer wall of other epidermal cells lying in the lower level of focus, since there is no superficial layer of wax or anything of that sort.

The epidermal cells of the cotyledon more or less differ from those of the leaf. In surface view they are rather irregular, and are elongated longitudinally. The size of each cell is larger than in the adult foliage leaf. In transverse section (Fig. 5) each cell appears broader than high. In my material there is no evidence of a cuticularized layer; the outer wall consists chiefly of cellulose, and is very much thicker than the other, and shows the middle lamella above referred to clearly. The thin cuticle covers the whole surface.

The epidermal cells of the young leaf are of irregular shape and larger size than those of the adult leaf, just as in the cotyledon. But when the development of the bundles of secondary origin begins, then the epidermal cells show a tendency to assume a more regular shape, and their size becomes smaller than that of those near the apex; this probably shows the beginning of the secondary structure of the leaf.

Two layers, cellulose and cuticularized, are already differentiated in $\mathrm{B}$ b 
the outer wall of the epidermal cell of the young leaf, in the latter of which are deposited minute granules of calcium oxalate.

The Stoma. Stomata are present on both surfaces of the leaf, and are situated in parallel rows, and in general are longitudinally orientated, as in most of the Conifers (Fig. 4). In the cotyledon they are arranged rather irregularly, and are orientated sometimes cbliquely, but in rare cases even transversely (Text-fig. I). I have also noticed in the cotyledon an immature stage of a 'twin-stoma' (Text-fig. 2).

In the adult leaf the subsidiary cells are much shorter than the surrounding epidermal cells and lie over the guard cells, so that very little of the latter is visible in surface view (Figs. 3, 4). In the three-week-old cotyledon
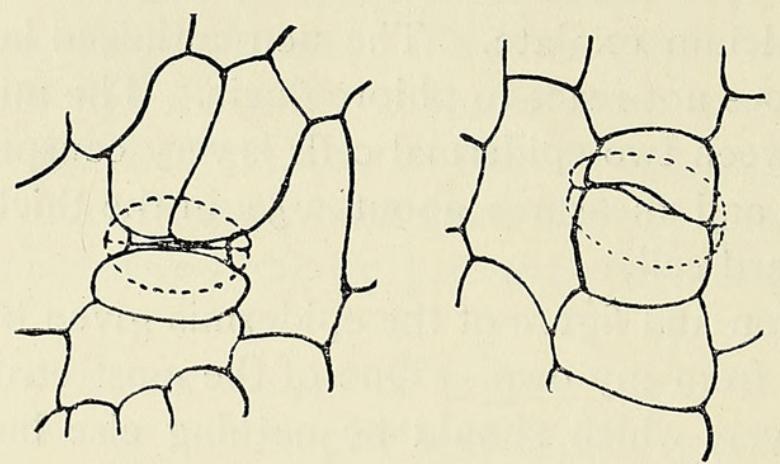

TEXT-FIG. I. Transversely orientated stomata from cotyledon. $\quad \times 285$.
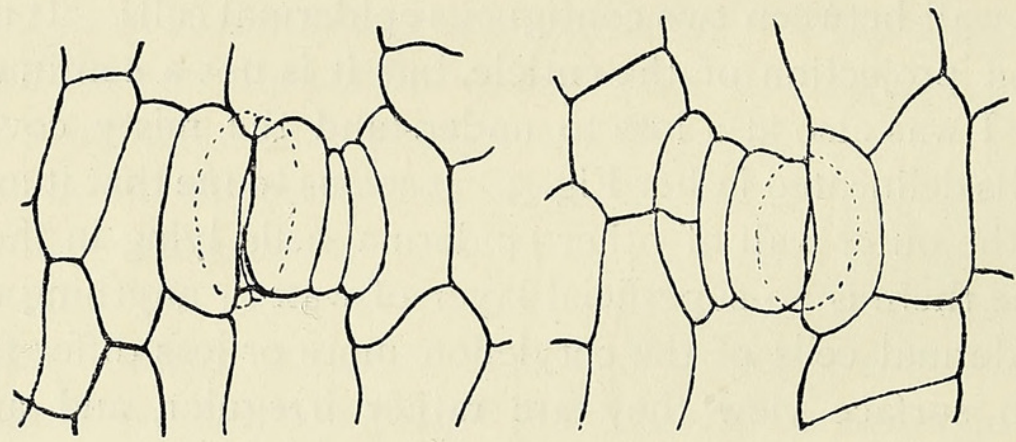

TeXT-FIG. 2. Immature stage of 'twin stomata' from cotyledon. $\times 285$.

and in the six-month-old leaf the subsidiary cells are scarcely shorter than the surrounding epidermal cells, and are only inclined towards the stoma (Fig. 5).

The guard cells are of the usual type of somewhat kidney shape (Fig. 2). In the median transverse section the outer ridge shows itself relatively prominent, and the inner ridge is wanting, as in Ephedra (Fig. 3). The dorsal wall is very much thickened, except at the base. The thickening on both the dorsal and ventral side of the guard cell is due, not to cutinization, but to lignification, as in Gnetum, Ephedra, Cycads, and Psilotaceae. At the end portion of the stoma, where the guard cells meet each other, the wall is also lignified (Fig. 2). The structure of the guard cell of the 
cotyledon and of the young leaf is much the same as that of the adult leaf, but the walls are less thickened. In my material of the cotyledon I have noticed that only the upper portion of the dorsal wall is lignified (Fig. 5).

The figures and descriptions of the stoma given by Sykes $(19, \mathrm{p} .182$, Pl. XVII, Figs. 2, 3) do not seem to be correct ; her Fig. 2 only represents a section cut near the end portion of the stoma, ' $M$ ' in this figure being not the ventral wall of the guard cell. ' $M$ ' in her Fig. 3 is very puzzling, because, in fact, ' $\mathrm{Z}$ ' in this figure corresponds to ' $M$ ' in Fig. 2.

The development of the stoma has been traced in the young leaf, and particularly in the cotyledon. An initial cell divides longitudinally into

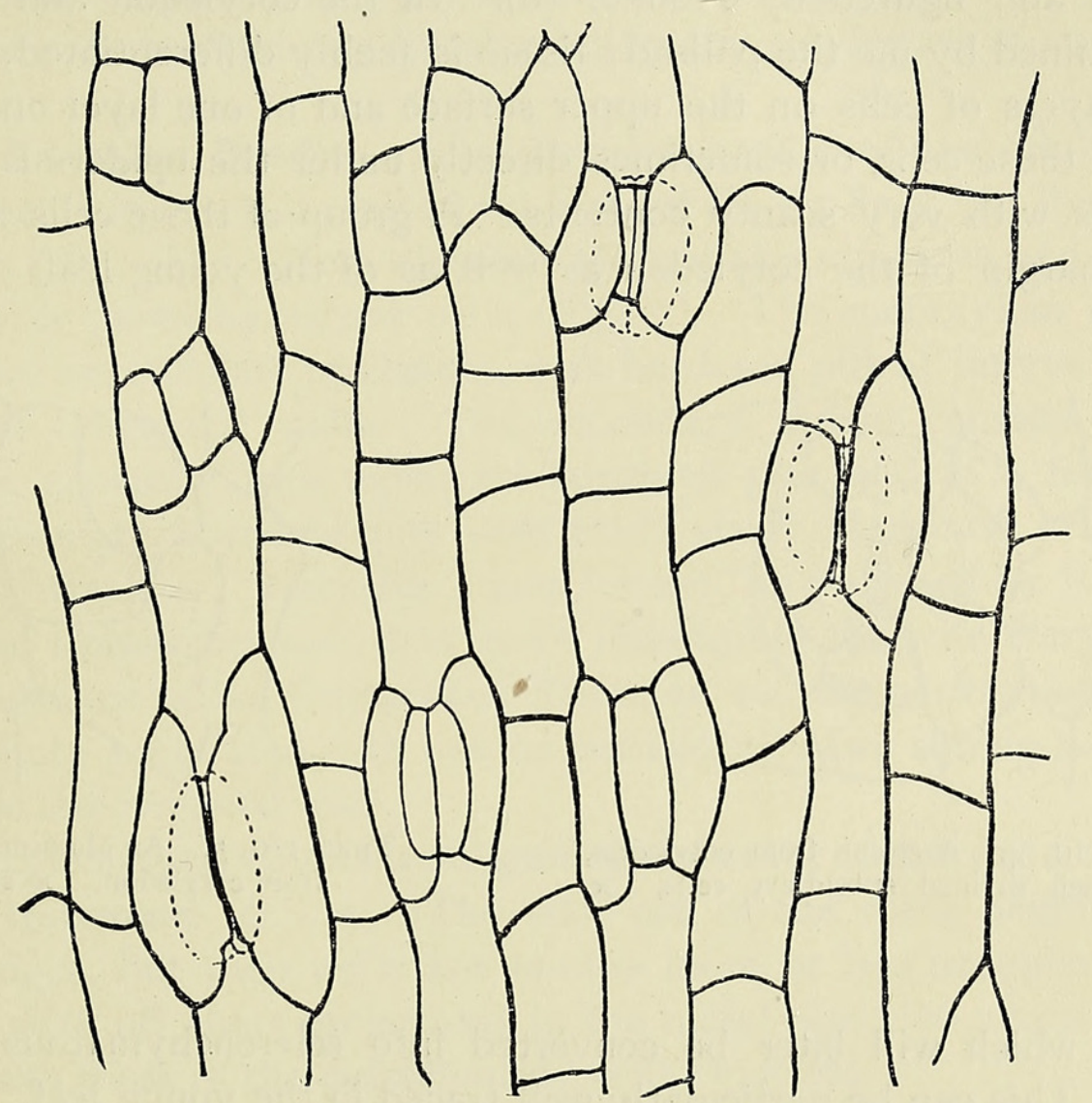

TexT-FIG. 3. A portion of epidermis from cotyledon, showing successive stages in the development of the stoma. $\times 285$.

two. One of the daughter-cells again divides in the same way, so that there are three cells formed. The two lateral ones become subsidiary cells, while the central one will be the mother-cell of the stoma. The mothercell divides longitudinally and forms the two guard cells. Thus a stoma with two parallel subsidiary cells is formed from one single initial cell. This is the simplest and probably the typical case (Text-fig. 3). One or both of the subsidiary cells may further divide transversely, longitudinally, or sometimes obliquely (Fig. 4, Text-fig. 4).

It has been observed occasionally that in the three-celled stage, which is the result of two successive divisions of the initial cell, a lateral cell, 
instead of the central one, becomes a stoma-mother-cell; then, although four cells will be formed by the last division, a cell belonging to the next row, which bordered this mother-cell, will function in the place of subsidiary cell (cf. Text-figs. I, 2). It seems to me that, at any rate in the cotyledon, occasionally even such an abnormality occurs as one of the cells of the twocelled stage directly becoming a stoma-mother-cell, while only three cells are cut off from the initial cell, one of which will become a subsidiary cell (Text-fig. 5).

The Mesophyll. This tissue of the adult leaf has been thoroughly described and figured by Hooker (8). In the cotyledon and the young leaf examined by me the palisade tissue is feebly differentiated, consisting of two layers of cells on the upper surface and of one layer on the other. Amongst these cells, or sometimes directly under the epidermis, one often finds cells with very scanty contents. A group of those cells also occurs on the margin of the cotyledon as well as of the young leaf. These are

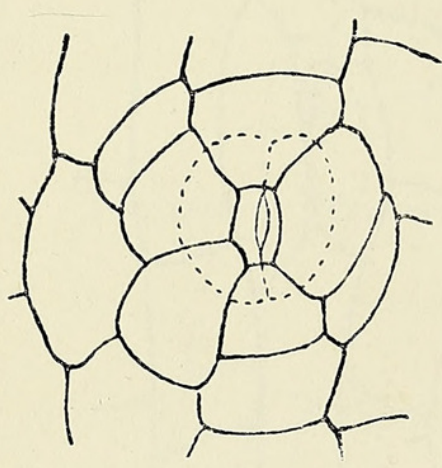

TEXT-FIg. 4. A stoma from cotyledon, showing much divided subsidiary cells. $x$ 285 .

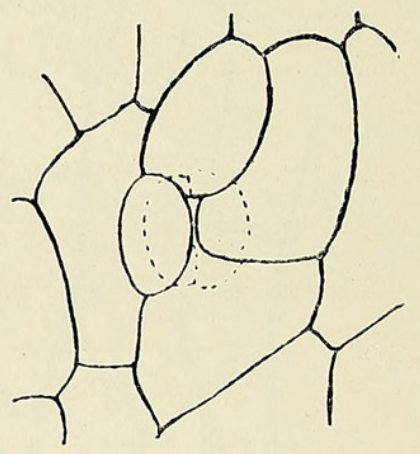

TEXT-FIG. 5. An abnormal stoma from cotyledon. $\times 285$.

the cells which will later be converted into sclerenchymatous fibres (cf. Fig. 9). This can be particularly well traced in the young leaf.

The centre of the leaf is occupied by thin-walled parenchymatous cells with intercellular spaces. They are isodiametric in shape, or more or less elongated longitudinally, and locally pitted. These and the palisade cells are full of protoplasm with chloroplasts, and constitute chlorenchyma. Sykes $(19$, p. I8I) assumes, without however giving any reason, that these cells function as water-storage organs. This assumption is, however, improbable, since the presence of the chloroplasts and intercellular spaces, as described above, does not admit of such a supposition.

In the adult leaf minute crystals of calcium oxalate occur in these isodiametric cells as well as in some of the palisade tissue bordering the former. The crystals are deposited on the cell-wall, but never in the celllumen. 
The Spicular Cell. There is no need of describing in great detail the well-known spicular cell. One can distinguish two layers of wall: an outer comparatively thin and lignified wall, and an inner thick and unlignified one; crystals of calcium oxalate are embedded in the former. Miss Sykes, however, in her description reversed the actual order. Her error seems to be due to a misunderstanding of Bower's correct statement: 'As the cell increases in size the cell-wall becomes differentiated into an outer cellulose wall and an inner lignified wall' $(3$, p. 590). What he means by 'outer cellulose wall' here is evidently nothing else but the middle lamella of the wall, from the inner layers of which the 'spicular cell ' becomes differentiated (cf. 3, Pl. XXXIII, Fig. I 7).

I have not observed any spicular cell in the cotyledons of my material.

The Vascular Bundle. The vascular bundle of the adult leaf has already been fairly well described by Hooker (8), de Bary (4), Bertrand (1), and Sykes (19). The xylem elements are radially arranged, and are interspersed with parenchymatous cells (Fig. 7). The metaxylem consists of dense spiral or reticulate tracheides, with bordered pits at intervals on their radial and tangential walls. The secondary xylem consists chiefly of tracheides, generally with uniseriate bordered pits, and of a few tracheae with multiseriate bordered pits with transversely elongated orifice (I use the terms 'trachea', 'tracheide', and 'vessel' as proposed by Rothert (cf. 12 , p. I6), simply because it is more intelligible than de Bary's usage). The tracheae are of the Gnetaceous character, viz. the perforation is incomplete, and are perforated with one or occasionally two simple large round, or more or less irregular pits.

The xylem-parenchyma is unlignified and never appears as a continuous ray in a transverse section. The cells are of the same height, and are never straight, but their walls are always more or less irregularly curved, and they give off short projections in the radial direction which come into contact with those of the neighbouring cells (Fig. IO).

The sieve-tube is much elongated and possesses an oblique end-wall. The sieve-plates are of the Gymnospermic type, and are present not only on the sloping wall, but also on the vertical wall of both the radial and tangential sides, as in Cycas, Dammara, and Ginkgo. They occur between two sieve-tubes as well as on the wall which abuts on the phloemparenchyma (Fig. II).

The phloem-parenchyma is disposed radially, and the cells are vertically elongated and are nearly uniform in height.

The transverse branch of the bundle has a similar structure to that of the main bundle on a much smaller scale. The xylem is composed chiefly of tracheides with reticulate thickening, with bordered pits at intervals. These connect with the metaxylem of the main bundle. Neither spiral 
nor annular vessels have been observed. The xylem-parenchyma is exceedingly scanty. There are no sclerenchymatous fibres present.

The structure of the vascular bundles of the cotyledon (Fig. 9) and of the young leaf hardly differs in essential points from that of the adult leaf. The xylem consists of annular and spiral tracheides of protoxylem, and of dense spiral and reticulate tracheides with scattered bordered pits. A few unlignified fibres occur on the phloem side (Fig. 9, scl.f.). In the mature part of the young leaf these fibres also occur on the xylem side.

The 'Transfusion-tissue'. This tissue is remarkably well developed in the leaf of Weluritschia, and has been described and figured by Hooker (7, p. I 9, P1. IV), de Bary (4, pp. 335, 382, Fig. I57), Bertrand (1, p. I6, P1. II, Fig. I), and Sykes (19, p. I 82, P1. XVII). I have here very little to add to de Bary's accurate and detailed description (4, p. 382). This tissue, which surrounds both the main bundles and veins, forms an almost complete sheath of tracheides of usually one or occasionally two layers. This tracheidal sheath is, in the case of the main bundle, usually separated from the vascular elements by either a layer of parenchyma on the side, or by a mass of sclerenchyma on the upper and lower side of the bundle. The cells lateral to the bundle are much narrower than the other; they are elongated and have reticulate thickening, while those above and below the bundle are much larger, nearly isodiametric, and have reticulate thickening or small bordered pits between meshes of the thickened bars (Fig. $7, w . t_{\text {. }}$ ). The degree of lignification of the cell-wall is, so far as the reaction of phloroglucin shows, less than in the xylem elements of the bundle, as Zimmermann (23, p. 7) observed in certain Conifers.

In my material of the three-week-old cotyledon and of the six-monthold leaf I have noticed some elements of the 'transfusion-tissue' have made their appearance on the lateral side of the larger bundles. Particularly towards the apex of the young leaf the 'transfusion-tracheides' are fairly abundant (cf. 19, p. I 83). They are usually separated from the bundle by a layer of parenchymatous cells, or occasionally join the xylem. Sykes states $(19$, p. 214$)$ that the first-formed elements arise on the phloem side of the bundle, but this is not the case with my material. The shape of the first-formed elements is more or less elongated in the direction parallel to the bundle. The membrane is lignified and possesses reticulate bars (Fig. 8, also cf. Fig. 9).

I have dealt with the significance of this tissue in general in a special paper (21).

The Mucilage Canal. In the adult leaf one often notices the presence of mucilage canals. These occur between bundles, and always on the phloem side. They are round in transverse section and comparatively short, varying from a few millimetres to as much as $\mathrm{I} \mathrm{cm}$. or more, and they run parallel 
to the long axis of the leaf. They arise lysigenously owing to deliquescence of certain mesophyll cells. Similar mucilage canals occur in all parts of plants, except in a very young seedling. According to Hooker $(9$, p. I 2$)$, even spicular cells are sometimes included in the contents of the canal.

\section{General Conclusions and Summary.}

It would not be advisable to draw phylogenetic conclusions from the anatomy of the leaf only. Yet there are not a few important points which exhibit the typical Gymnospermic characters, and especially show a close relationship to other members of the Gnetales.

The paired bundles in the cotyledon, the leaf (here the primary bundles alone should be taken into account), and in the bracts, ${ }^{1}$ which are derived from the 'double leaf-trace', are worthy of notice. The paired bundles are to be seen in the leaf and bract of Ephedra, whereas in Gnetum this point is of more Angiospermic character.

The leaves are always opposite and decussate in these three genera, although tricyclic leaves sometimes occur in Ephedra.

Cyclic leaves are not known in any other group of Gymnosperms except in Cupressineae and in Araucarineae (Dammara).

It has been pointed out that the base of the cotyledons in Welreitschia is connate. The connate leaf-base is to be seen in the leaves and bracts of these three genera. In Gnetum the leaves are very slightly connate, so that this character is not clearly comprehended in an older stage.

The structure of the stoma is also on the whole similar in all these genera. The development of the stoma is very much the same in Welwitschia and in Gnetum (22).

The hypodermal sclerenchyma with unlignified wall is present in these three genera.

One of the interesting features is the occurrence of crystals and granules of calcium oxalate in the cell-wall of various parts of the plant, such as the epidermis (16, p. 54I ; 4, p. I02) and mesophyll (16, p. 52I ; 4, pp. I4I, $335)$ of the leaf, in the spicular cell $(16$, p. $527 ; 4$, p. 133), in the epidermis (1, p. I4) and parenchyma (16, p. 52I) of the stem, and in the soft tissue of the root. This character prevails in Conifers ${ }^{2}$ and very seldom occurs

1 A detailed account of morphology of the bracts will be dealt with in a special paper.

2 I have observed myself this phenomenon in various parts of the following plants: I. Spicular cells with crystals in Araucaria imbricata (leaf and pith), Acmopyle Pancheri, Dammara australis, Fokienia Hodginsii, Sciadopitys verticillata (leaf), Torreya californica and 7 . taxifolia (cortex). 2. Crystals deposited in the cortex (in the widest sense) of Araucaria imbricata, Callitris rhomboidea, Fitzroya patagonica, Juniperus communis, Libocedrus decurrens, Saxe-Gothaea conspicua, Sciadopitys verticillata, T'axus baccata, Thuja sp., Torreya californica, T. taxifolia, Wellingtonia gigantea, and Widdringtonia cupressoides (also cf. I6). 3. In pith of Araucaria imbricata, Saxe-Gothaea conspicua, and Torreya californica. 4. In the outer wall of the epidermis of certain species of the following twenty-nine genera : Abies, Acmopyle, Actinostrobus, Athrotaxis, Callitris, Cedrus, Cephalotaxus, Cryptomeria, Cunninghamia, Cupressus, Dammara, Fïtzroya, Fokienia, Glyptostrobus, Juniperus, Libocedrus, Phyllocladus, Picea, Pinus, Prumnopitys, Pseudotsuga, Sequoia, Sciadopitys, Taizeania, Taxodium, Taxus, Tetraclinis, Tsuga, and Widdringtonia. 5. In chlorenchyma of all known coniferous genera except Larix and Pseudolarix, where $\mathrm{I}$ have failed to detect any trace of this substance, probably being due to my material. 
in Angiosperms (13, p. I107; 11, p. 98, tab. 3, Figs. I-3; cf. also 13, p. 2). It is also interesting to notice that in Ephedra this mineral salt occurs in the cell-wall, while in Gnetum, Ginkgo, Ceratozamia, Cycas, Dioon, Encephalartos, and Zamia, it is deposited in the cell-lumen as clustered crystals. absent.

The phloem is of the Gymnospermic type, the companion cell being

The presence of tracheae seems somewhat to enfeeble our view of regarding these three genera as Gymnosperms, yet the perforation is not typical Angiospermic, but incomplete, showing only transition. Another interesting point is that the mode of the development of the bordered pits in Gnetales is of the type predominant in Conifers (on this subject another paper is in view).

From the facts here mentioned I consider Welwitschia and all other members of Gnetales as Gymnosperms, and cannot agree with the hypotheses recently put forward by Hallier $(5,6)$ and Lignier and Tison $(9,10)$. I am also not in favour of the hypothesis that the Gnetales havea closer relationship to the Cycadales than to the Coniferales. As far as the anatomical features are concerned, Welwitschia is more closely related to Ephedra than to Gnetum.

In conclusion I express my hearty thanks to Professor Farmer for his kind criticism.

\section{BIBLIOGRAPHY.}

1. Bertrand, C. E. : Anatomie des Gnétacées et des Conifères. Ann. Sc. Nat., Bot., sér. 5, xx, 1875 .

2. Bower, F. O.: On the Germination and Histology of the Seedling of Welwitschia mirabilis. Quart. Journ. Micr. Sc., xxi, I88r.

3. $:$ On the Further Development of Welwitschia mirabilis. Ibid.

4. DE BARY, A. : Comparative Anatomy of Phanerogams and Ferns. Engl. Trans., 1884.

5. Hallier, H. : Provisional Scheme of the Natural System of Flowering Plants. New Phytologist, iv, 1905 .

6. : Ein zweiter Entwurf des natürlichen Systems der Blütenpflanzen. Ber. d. D. Bot. Gesellch., I905.

7. Hill, T. G., and DE Fraine, E. : On the Seedling Structure of Gymnosperms, IV. Ann. Bot., xxiv, I9IO.

8. Hooker, J. D.: On Welwitschia : a New Genus of Gnetaceae. Trans, Linn. Soc. London, Bot., xxiv, I 863 .

9. Lignier, O., et Tison, A. : Les Gnétales sont des Angiospermes apétales. Compt. Rend. Acad. Sci., cliii, I9I I.

10. - Les Gnétales. Ann. Sc. Nat., Bot., sér. 9, xvi, nos I à 3, I 9 I 2.

11. Pfitzer, E. : Ueber die Einlagerung von Kalkoxalat-Krystallen in die pflanzliche Zellhaut. Flora, lv, I 872 .

12. Rothert, W.: Ueber den Bau der Membran der pflanzlichen Gefässe. Bull. Acad. Sc. Cracovie, 1899 . 
13. Rothert, W.: Ueber die anatomischen Differenzen der Gattungen Dracaena und Cordyline. Bull. Dép. Agr. Ind. Néerland., No. 24 , 1909.

14. Scheit, M. : Die Tracheidensäume der Blattbündel der Coniferen, etc. Jenaische Zeitsch. f. Naturwissenschaft, xvi, I 883 .

15. Solereder, H.: Systematic Anatomy of the Dicotyledons. Engl. Trans., 1908.

16. Solms-Laubach, Graf zU: Ueber einige geformte Vorkommnisse oxalsauren Kalkes in lebenden Zellmembranen. Bot. Zeitg., I87 I.

17. Strasburger, E. : Die Coniferen und die Gnetaceen. 1872.

18. $:$ Leitungsbahnen. I $89 \mathrm{I}$.

19. Sykes, M. G.: The Anatomy and Morphology of the Leaves and Inflorescences of Welwitschia mirabilis. Phil. Trans., cci, ser. B, I910.

20. : The Anatomy of Welvitschia mirabilis, Hook. f., in the Seedling and Adult States. Trans. Linn. Soc. London, Bot., ser. 2, vii, I9Io.

21. TAkedA, H.: A Theory of 'Transfusion-tissue'. Ann. Bot. xxvii, I9 I3, p. 359.

22. - Development of the Stoma in Gnetum Gnemon. Ibid., p. 365 .

23. Zimmermann, A.: Ueber das Transfusionsgewebe. Flora, lxiii, I880.

\section{EXPLANATION OF FIGURES IN PLATE XXIX.}

Illustrating Mr. Takeda's paper on the Leaf Anatomy of Welwitschia mirabilis.

All figures were drawn with the aid of Abbe's drawing apparatus.

Fig. I. Cotyledon showing the nervation. $\times 4 \frac{\mathrm{I}}{2} . C . b .=$ central bundle. $L . b .=$ lateral bundle. M.b. = marginal bundle. Conn. = connate portion at the base.

Fig. 2. Stoma in surface view. From a horizontal section cut at the level of the outer ridge of the guard cell. $\times 450$.

Fig. 3. Epidermis of the under surface of the leaf. Stoma are cut at the median portion. $\times$ 450. $C$. = cuticle. $C . l .=$ cuticularized layer. $M . l .=$ middle lamella. $C . w .=$ cellulose wall. Scl. $f .=$ sclerenchymatous fibre. Spic. $=$ spicular cell. Pal. $=$ palisade parenchyma.

Fig. 4. Surface view of the epidermis of the undar side of the leaf. $\times 28_{5}$.

Fig. 5. A portion of a transverse section of the cotyledon (under surface). $\times 450$.

Fig. 6. Longitudinal section of a stoma of the upper surface of the leaf. $\times 450$. Lettering is same as in Fig. 3.

Fig. 7. Transverse section of a vascular bundle of the leaf. $\times 285$. Pr. $x_{0}=$ protoxylem. $W . t .=$ water-storing tracheides. $X . p_{0}=$ xylem parenchyma.

Fig. 8. Water-storing tracheides of the cotyledon. From a longitudinal section; compare with Fig. 9. $\times$ 500. $C h l_{0}=$ chlorophyll-containing cell.

Fig. 9. Transverse section of the main bundle of the cotyledon. $\times 45^{\circ}$. Pr.x. $=$ protoxylem. Pr.ph. $=$ protophloem. $S c l . f_{.}=$sclerenchymatous fibre. $W . t .=$ water-storing tracheide.

Fig. IO. Portion of the xylem-parenchyma. From a longitudinal section of the leaf; compare with Fig. $7, X . p . \quad \times 285$.

Fig. I I. Portion of sieve-tubes and phloem-parenchyma. From a horizontal section of the leaf. $\times 500$.

Fig. I2. A portion of a longitudinal section of vessels. $\times 45^{\circ}$. 
Annals of Botany

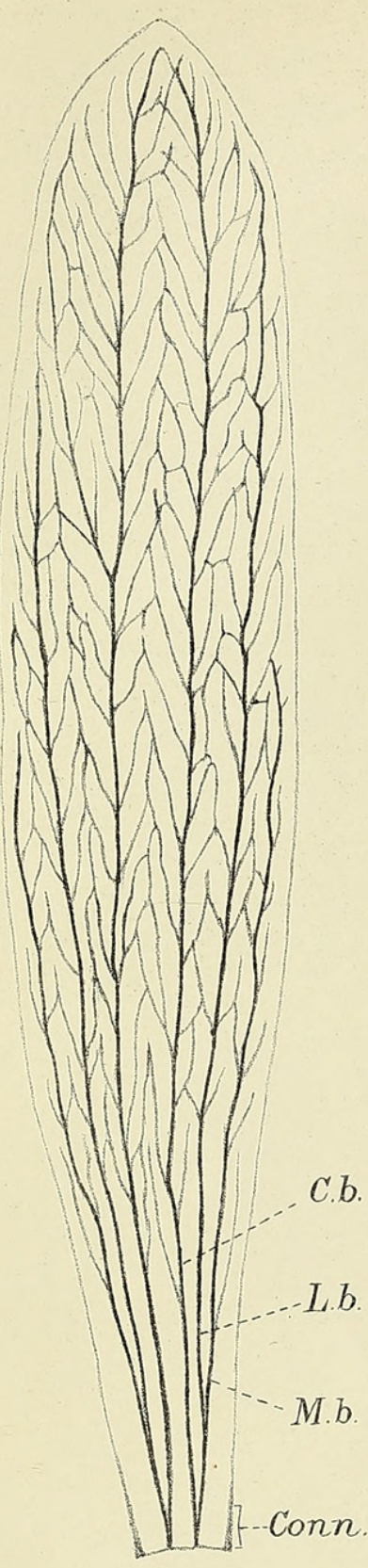

1.

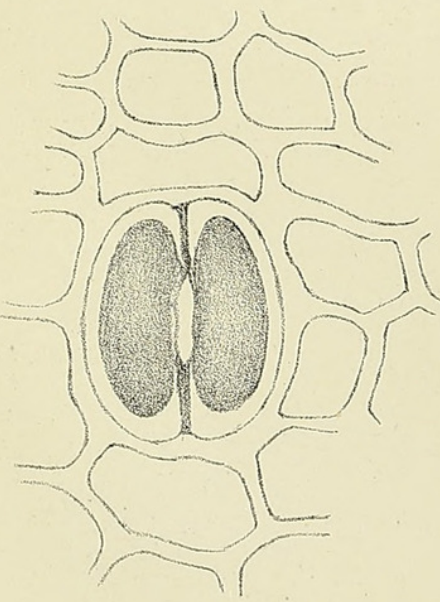

2.
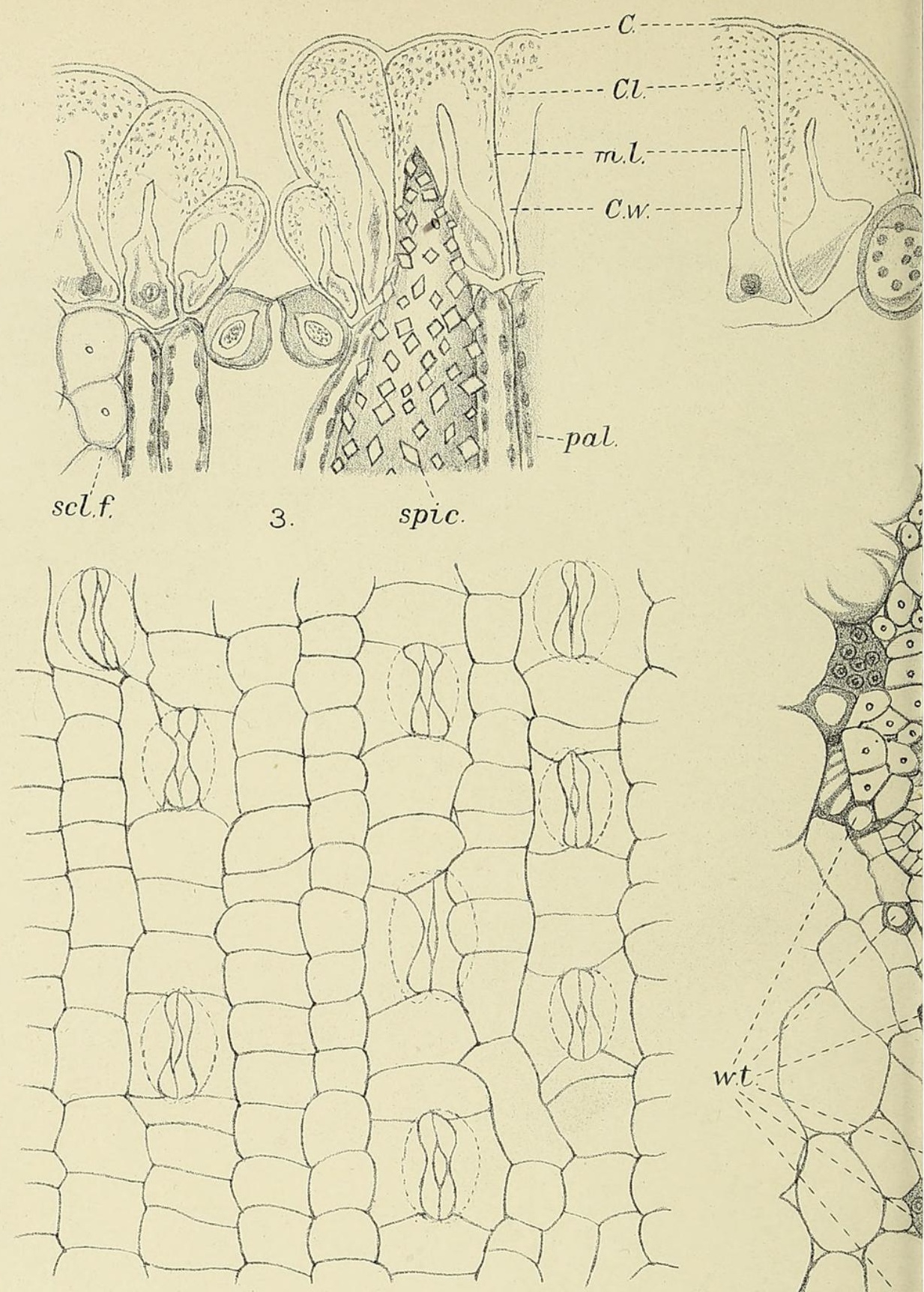

4.

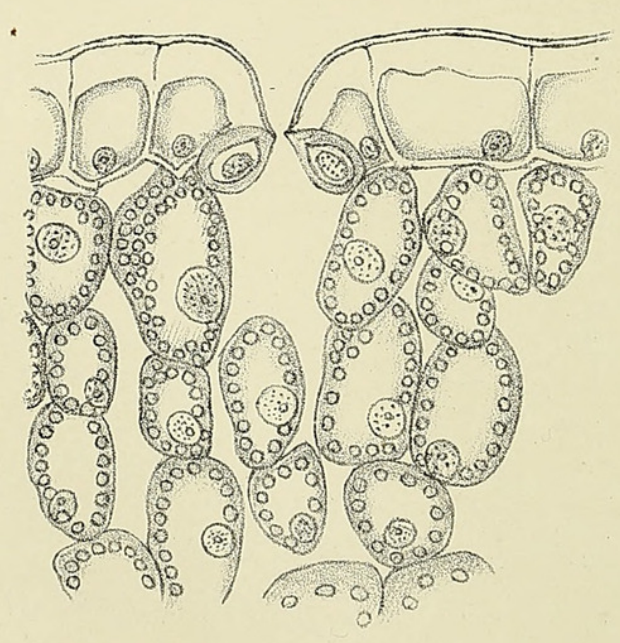

5.

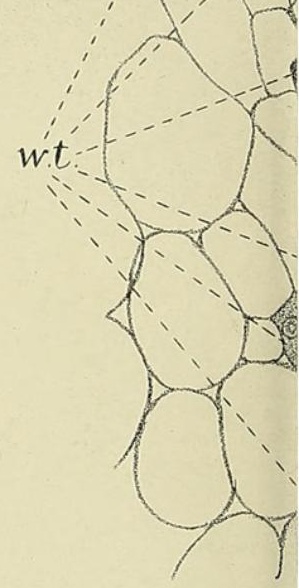




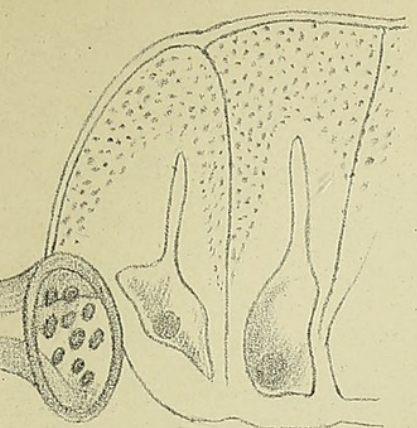

6.

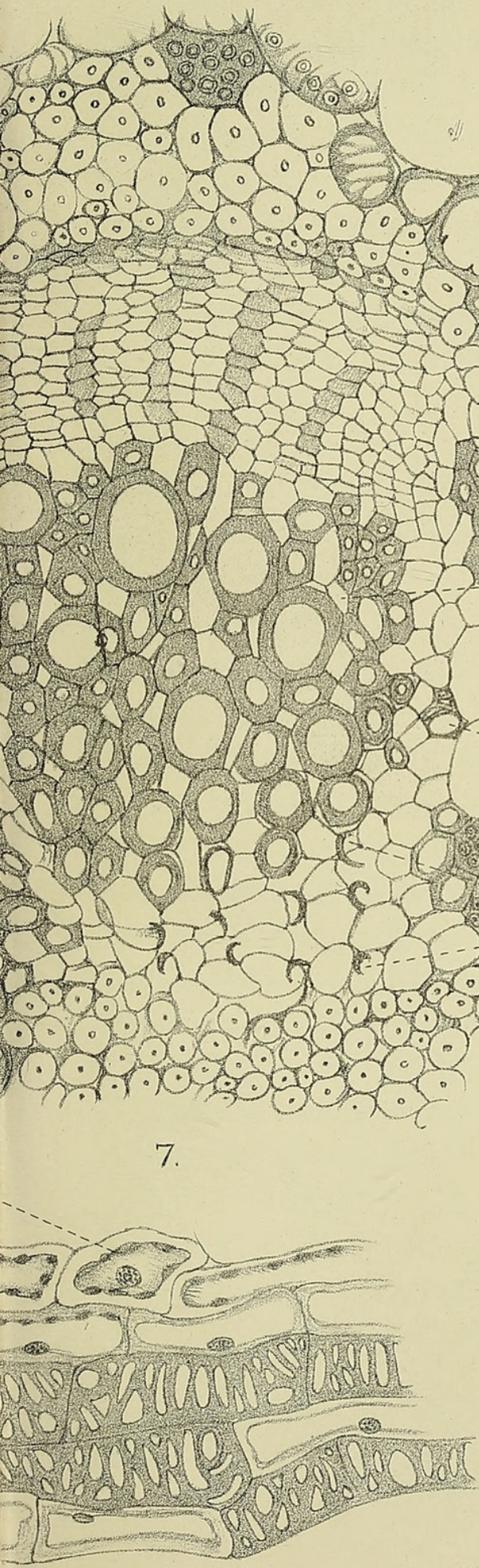

8.

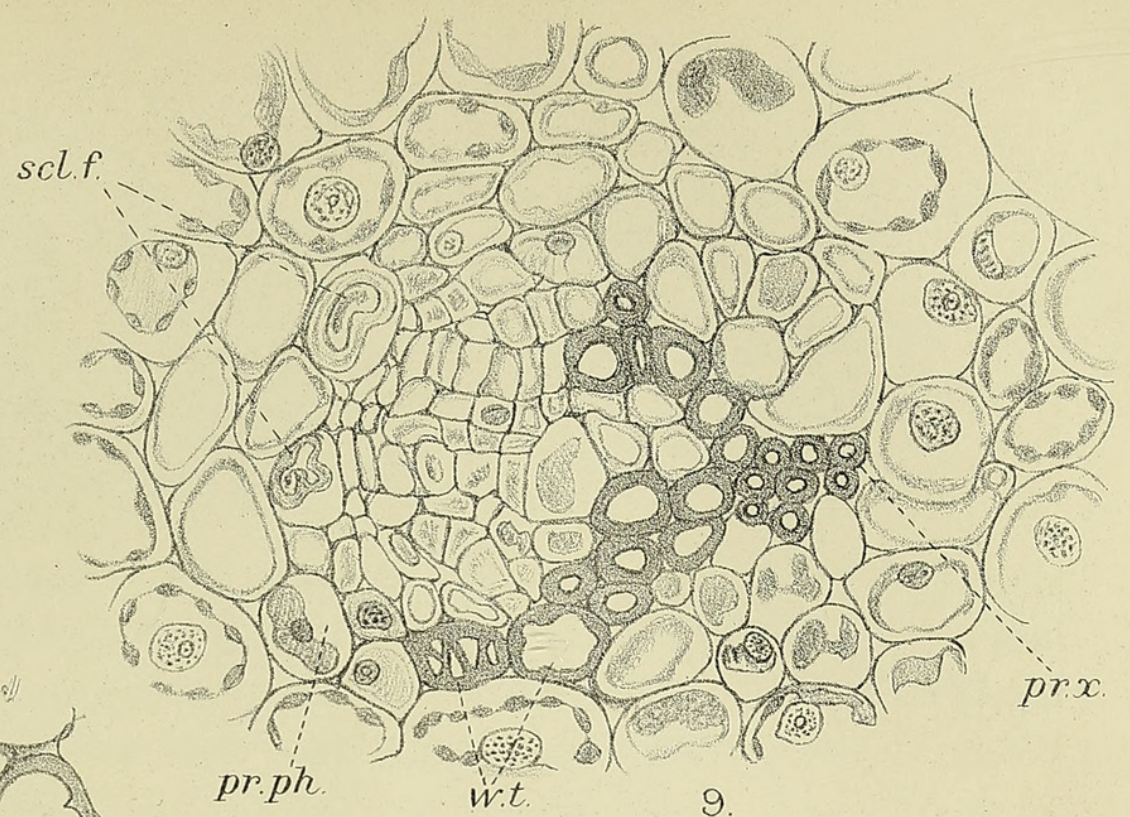

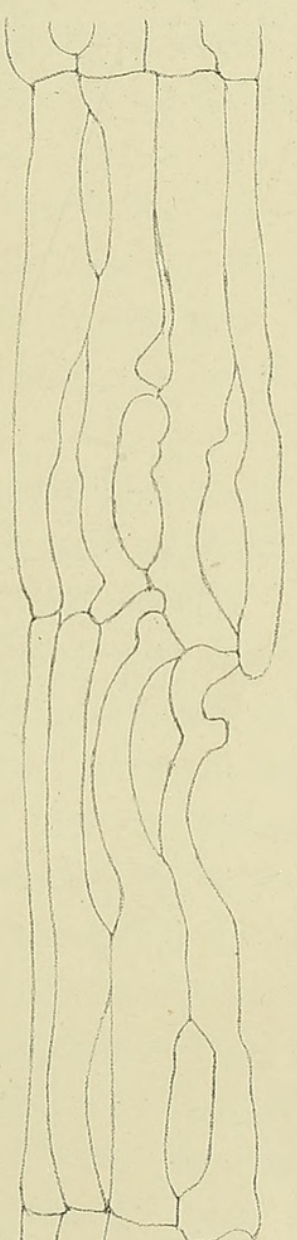

10

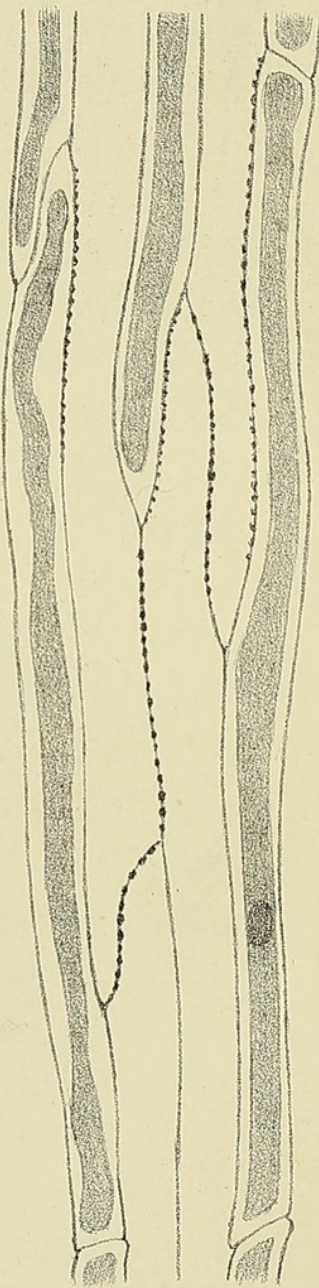

11.

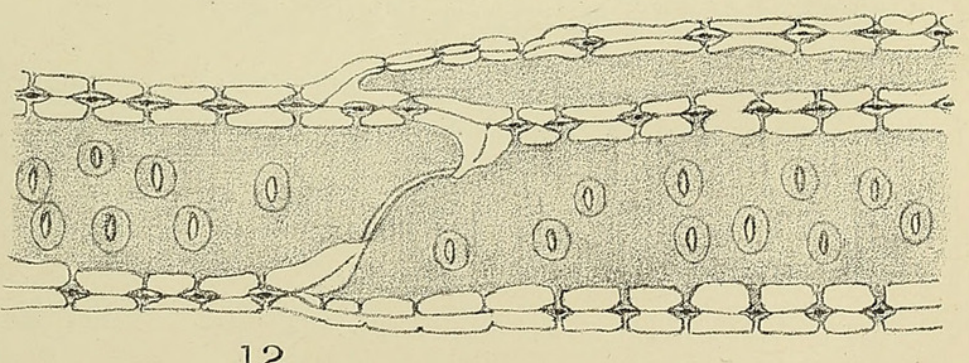

12. 

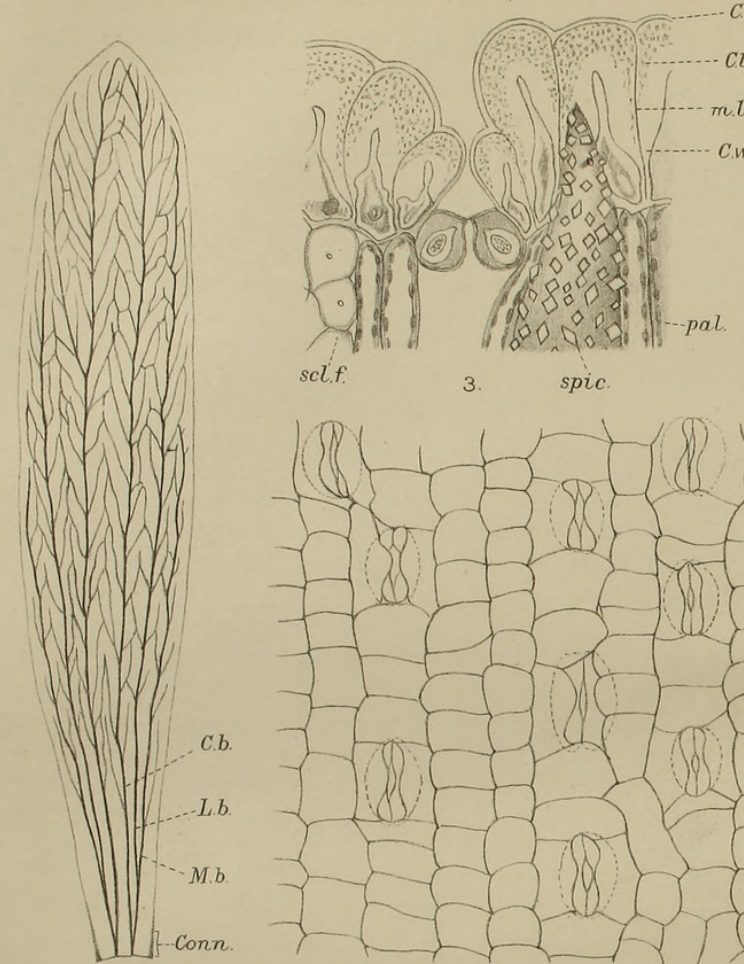

1.

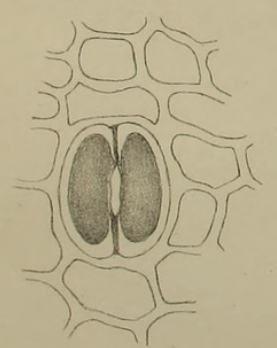

2.

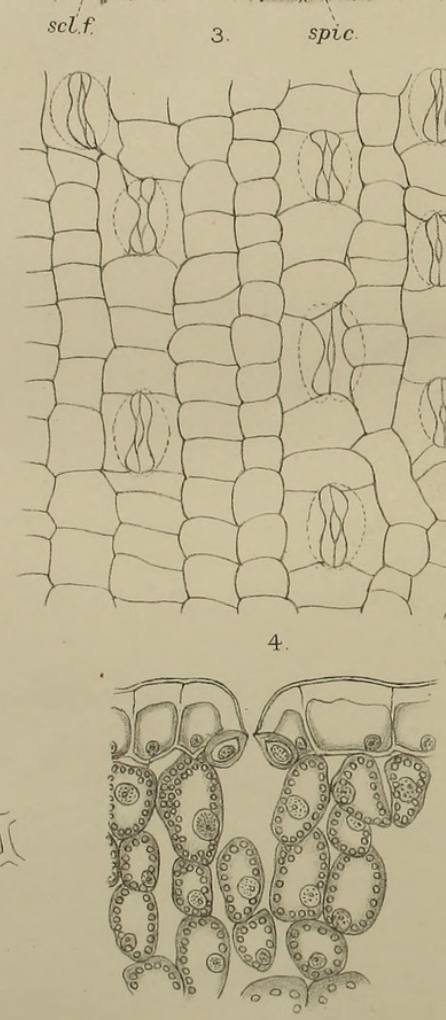

5.

TAKEDA.- WELWITSCHIA
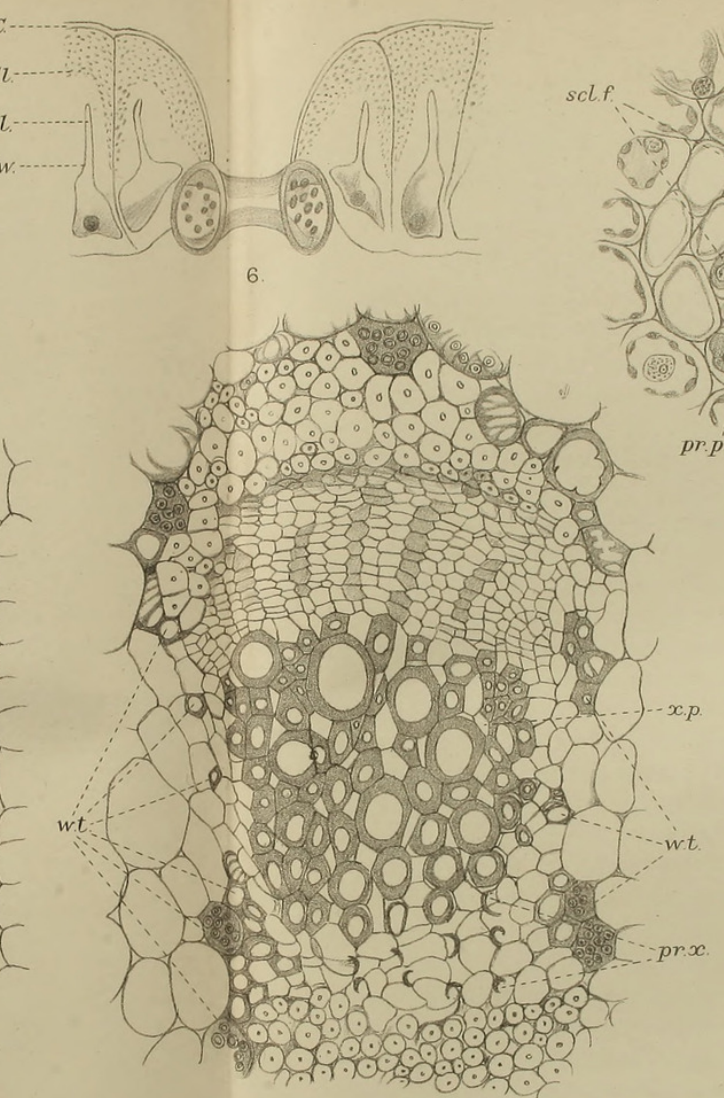

7.

chl

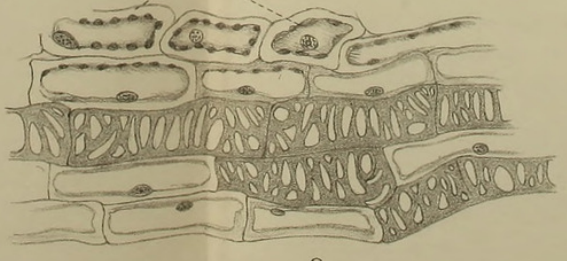

8.

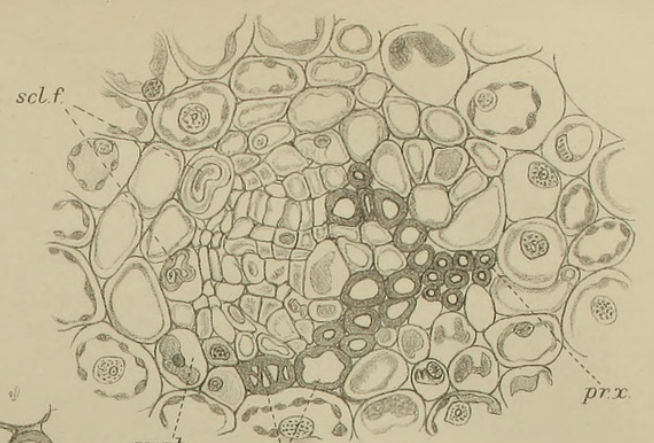

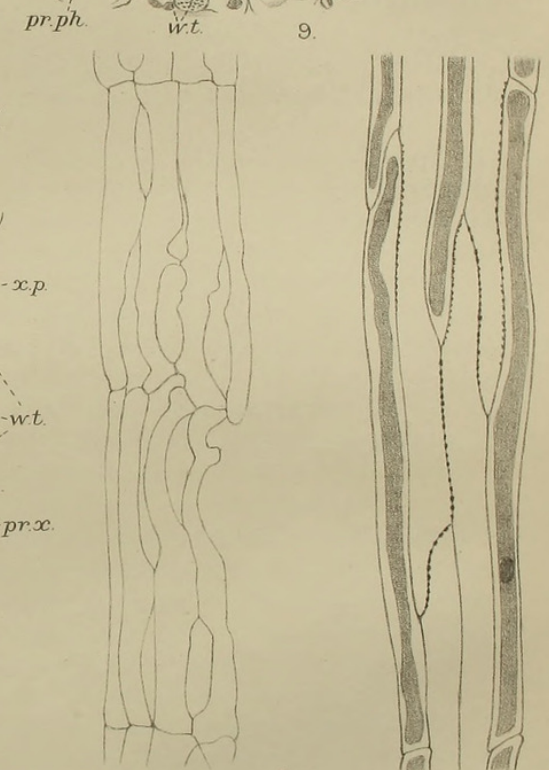

10.

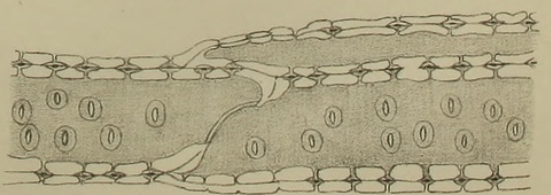

12

Huth,lith et imp 


\section{$2 \mathrm{BHL}$ Biodiversity Heritage Library}

Takeda, H. 1913. "Some points in the anatomy of the leaf of Welwitschia mirabilis." Annals of botany 27, 347-357.

https://doi.org/10.1093/oxfordjournals.aob.a089462.

View This Item Online: https://www.biodiversitylibrary.org/item/237410

DOI: https://doi.org/10.1093/oxfordjournals.aob.a089462

Permalink: https://www.biodiversitylibrary.org/partpdf/319975

\section{Holding Institution}

Smithsonian Libraries

\section{Sponsored by}

Biodiversity Heritage Library

\section{Copyright \& Reuse}

Copyright Status: Not in copyright. The BHL knows of no copyright restrictions on this item.

This document was created from content at the Biodiversity Heritage Library, the world's largest open access digital library for biodiversity literature and archives. Visit BHL at https://www.biodiversitylibrary.org. 